\title{
The Use of Farm Information Systems among Grasscutter Farmers in Ga-South Municipality and Awutu-Senya District in Ghana
}

\author{
Justice G. Djokoto \\ Department of Agribusiness, Central Business School, Central University College \\ P. O. Box DS 2310, Dansoman, Accra, Ghana \\ Tel: 233-28-503-7399 E-mail: dgameli2002@gmail.com
}

Received: January 25, 2012

Accepted: February 8, 2012 Published: March 1, 2012

doi:10.5539/cis.v5n2p55

URL: http://dx.doi.org/10.5539/cis.v5n2p55

\begin{abstract}
The paper investigated farm information systems use among grasscutter farmers in Ga-South and Awutu-Senya District in Ghana. Using frequency, cross tabulations and binary logit model in Statistical Package for Social Sciences (SPSS) version 18, the study made some findings. Grasscutter farmers in the study area are ageing. They operate on small scale with males dominating the enterprise. The generally literate farmers used production records mostly. Farmers' use of farm information systems did not show positive association with obtaining credit from formal credit institutions. The use of books and loose sheets to keep records of farm operations is most popular with the farmers. Use of computers is least popular. Too much work, no reasons for non-use, and inadequate time at their disposal to spare some for recording were some of the reasons adduced for not using farm information systems. Age, level of education, farm size, and farmer status, membership of association, sex, experience and income were found to be independent of farm information systems use. Government and non-governmental organisations must encourage young persons especially females to engage in the enterprise. An investigation into the causes of low farm size will unearth the causes and as such provide ways to increase farm size as most of the farmers are into full time grasscutter rearing. Members of grasscutter farmers association need to step up their membership drive to recruit more farmers into the association as associations are better to relate to and reach with extension effort.
\end{abstract}

Keywords: Ga-South Municipality, Awutu-Senya District, Farm information systems, Grasscutter farmers, Cane rat farmers

\section{Introduction}

\subsection{Background}

The need for, use and benefits of information for farm decision making has engaged the attention of farmers, researchers and policymakers over the years. Information is data that has been transformed into a form that is meaningful and useful for decision-making (Laudon \& Laudon 2002) with data distinguished as raw facts, figures, objects et cetera. The 'system' about information relates to the connection or integration of components of collection, processing, storage, and distribution of information to support decision-making (Laudon \& Laudon 2002). By extension of this non-farm definition, farm information systems (FIS), then, can be appreciated as a tool to assist farms in forward planning, risk management, and control (Adams, 2009) by the use of information (Doye, et al., 2000). Grasscutter production enterprises require good information systems to ensure success.

Grasscutter (Thryonomys swinderianus), also known as cane-rate, is a large terrestrial rodent with total weight ranging from $5-7 \mathrm{~kg}$ (Happloid, 1987). It has thick and coarse dorsal hairs mostly brown with yellow band at its terminal and usually black tip. Originating from the savannah, it has successfully penetrated the forest zone. In the wild, it lives among dense grass reeds near water sources such as rivers and swamps with good vegetation cover (Onadeko, 1996). Grasscutter is the most preferred bush meat source in Africa (Asibey, 1974, Vos, 1978, Clotey, 1981; Martin, 1985; Kyle, 1987; Van de Velde, 1991; NRC, 1991) including Ghana. Grasscutter is suitable for meat (Heull-Rolf, 2002; Wontewe, 2002). The meat has good nutritional value and superior in taste to other domestic game species, with average dressing percentage of 65 (Ajayi \& Tewe, 1980). Byanet et al, (2009) has reported higher protein, mineral, and lean meat, as well as non-cholestrogenicity and high digestibility. The taste and carcass composition makes it acceptable (Ajayi \& Tewe, 1980, Feyenuwo, et al. 
1998). Parts of the animal are used as ingredients for traditional medicine (Taiwo, 2006); preparation of concoctions for fertility and healing of wounds are made from it. The pancreas, which is high in insulin, is used for local treatment for diabetes. Grasscutter easily multiplies (Ajayi \& Tewe, 1980; Feyenuwo et al., 1998) and contributes to both domestic and export earnings of Ghana (Asibey, 1969; NRC, 1991). Households in parts of Ghana engage in grasscutter rearing as full time engagement as well as supplemental income (Heull-Rolf, 2002; Wontewe, 2002; Adekoya, 2007), and Ga-South Municipality and Awutu-Senya District are no exception.

Awutu-Senya district with its capital as Awutu Breku forms part of the new districts and municipalities created early in 2008. The district was created out of Awutu-Afutu-Senya Municipality since the latter was too large for effective administration. The district located in the Central Region of Ghana shares its eastern border with Ga-South Municipality and is bordered on the west by Afutu Municipality. Blessed with the sea on its southern border, some inhabitants engage in fishing. Others participate in other agricultural activities and trading. Ga-South is one of the recent municipalities designated by the government of Ghana. It shares its eastern boundary with the metropolitan area of Accra, the capital of Ghana. On the west is the Awutu-Senya District of the Central region and on the north is Ga-West Municipality. The Gulf of Guinea terminates the southern boundary of Ga-South Municipality. Inhabitants of the municipal area engage in diverse occupations including fishing and farming. Grasscutter farming is one of the farming occupations that engage the attention of some households.

\subsection{Problem Statement}

Many low-income households consume more plant protein than animal protein owing to cost in spite of the utility of animal protein to the body (Akinbile, 2002). There is therefore the need to identify alternative sources of animal protein that are cheaper to produce to encourage animal protein consumption. In promoting business of any size, the establishment of information systems and development of networks and information infrastructures and information technology are important for success (Hadawy et al., 2011). Recognising the importance of Grasscutter farming and the need to use information systems for production success, the following questions arise: what are the demographic characteristics of Grasscutter farmers? What farm information systems do Grasscutter farmers use? Which demographic factors influence farm information system use attitudes? Finally, what constraints militate against farm information systems' use among grasscutter farmers in Ga-South Municipality and Awutu-Senya District?

\subsection{Objectives}

To respond to the questions posed, the study seeks to:

- examine the demographic characteristics of the Grasscutter farmers

- identify the various types of farm information systems used by the Grasscutter farmers

- describe the implications of farm information systems and

- identify the reasons for non-use and constraints of grasscutter farmers in using farm information systems

- determine the factors affecting use of farm information systems by grasscutter farmers

\subsection{Relevance}

In the last three decades, Ghana has made efforts to diversify her sources of foreign exchange. The export demand and supply potentials of Grasscutter make the rodent a product for promotion. The domestication and increased production of Grasscutter in captivity holds promise for reduction in bushfires caused by bush meat hunters. Tham-Agyekum et al. (2010) studied record-keeping among poultry farmers in Ga-East Municipality. Farm management experts frequently posit that good farm information systems are essential in improving farm efficiency and profitability (Grisham \& Gillespie, 2008; Engler \& Toledo 2010). Investigating the types of production and financial records producers are keeping, who are keeping them and whether the records are manual or computerised is beneficial for design of extension programmes. The two local government areas are located at the coastal fringes of the relatively urban administrative regions of the country. Their nearness to the capital city Accra is a potential for market of Grasscutter meat. Thus practices that would promote Grasscutter meat production and improve income of farmers require research attention.

\subsection{Organisation of Study}

The rest of the paper is composed into three sections. Section 2 presents review of literature pertinent to the title of study. Section 3 presents data and methods of analyses. Section 4 contains the results and accompanying discussions. Reporting the research concludes in section 5 with the associated recommendations. 


\section{Literature}

\subsection{Records, Mode of Keeping, Frequency, and Use}

Over the past decade, educators have promoted record-keeping by developing hand recording systems and software. Yet, farm record-keeping is still a neglected farm activity (Doye et al., 2000). Lasley \& Agnitsch (2002) found that out of a sample of 1,960 farmers polled in Iowa State, a third of them dislike record-keeping/paper work. Hewlett (undated) noted that several options exist for handling farm information system; which range from paper forms to be filled by hand to computerised systems. Tham-Agyekum et al. (2010) established in a study of 50 poultry farmers in Ga-East Municipality in Ghana that $100 \%$ of the respondents kept some form of farm record. Most farmers keep their farm records manually (Jeyabalan, 2010). And one of the six respondents in a case study research by Doye et al. (2000) was keeping records manually before he purchased a computer. Ryde \& Nuthall (1984) stated that the majority (about 80\%) of farmers kept their records hand written, that is in books, ledgers, bills and other loose leaves. Alvarez \& Nuthall (2001) studied a sample of 290 farmers in Canterbury, New Zealand. They found that farmers kept both financial and production records. No respondent kept financial records in human memory. Additionally, $26.20 \%$ of the respondents kept a manual record. About 54.48\% kept computerised records. About $20 \%$ stored feed records in their memory whilst majority (48.97\%) used manual recording for feed. About $17 \%$ of the 290 respondents used computers for feed recording. A meagre $1 \%$ stored livestock records in memory, whilst a majority of $41 \%$ used a manual recording for livestock. The second highest percentage (35.17\%) represented those who used computers to store livestock records. Together, more than $60 \%$ of farmers used at least one computerised information system, while only $10 \%$ used a computer for all three areas. Ferrer, et al., (2003) established that $97 \%$ of respondents owned computers and applied it for record-keeping among other uses. Tham-Agyekum et al. (2010) concluded that a large proportion ( $82 \%$ ) of poultry farmers sampled, kept their farm records manually, that is in books, sheets of papers and temporarily on walls to later transfer into record books. Only $2 \%$ adopted the computerised system, using mainly Microsoft Office Word and Microsoft Office Excel and 16\% tended to use both systems (manual and computerised). Indeed farm information systems include both manual and computerised records (Doye et al., 2000). Computerised record-keeping systems improve the timeliness and accuracy of decision-making (Jofre-Giraudo et al., 1990). Jayabalan (2010) noted that manual record-keeping is usually time consuming, tedious to find important data and make decisions. Yet, 'although all managers in the case studies use computers, hand records remain key components in some instances' Doye et al., 2000, p. 583). Studies by Batte et al., (1990), Batte et al., (1995) and Wojan (2000) found many farmers used computers for record-keeping and financial analysis. In spite of the decision making advantage of record-keeping Ryde \& Nuthall, (1984), Carkner (2000) and Doye et al. (2000) noted that farmers do not refer to the records daily, some as late as a month after. In fact as many as $78.9 \%$ of 660 respondents updated and checked records up to a month. Devonish et al., (2000) and Okantah et al., (2003), both cited in Tham-Agyekum et al. (2010) disagree on this. Whilst the former confirms Ryde \& Nuthall (1984)'s finding, the latter held a contrary view. That is; for the farmers studied, most (38\%) preferred to record their data weekly, whiles $30 \%$ preferred monthly basis and $28 \%$ recorded data daily. Time spent keeping records varied between 6 to 80 hours per month (Doye, et al., 2000).

\subsection{Types of Farm Records}

Gerloff \& Holland (1995) classified farm records into two; production and financial records. Production records include items that relate to quantities of inputs and levels of production by enterprise and/or by resource type. They consist of crop yields, plant populations, calves born, volume of milk produced, weaning weights, and death loss, among others. In grasscutter production, these will include feed, labour, mortality, birth and breeding, weight of new animals sold, the amounts of feeds and drugs or vaccines administered. Financial records on the other hand, relate primarily to money or the financial interactions of the farm. Product sales, operating expenses, equipment purchases, creditors, debtors, inventories, depreciation records, loan balances and price information are all examples of financial records. However, Poggio (2006) isolated resources inventories from Gerloff \& Holland (1995)'s financial records and introduced supplementary records defined to include survey map, the farm layout (map) and the legal documents of the farm. Tham-Agyekum et al. (2010) followed the classifications of Omoruyi (1999) and Poggio (2006). A fourth element in their classification is resource inventory. This captures assets and liabilities of the farm. Extensive production records were kept on intensive production enterprises (Doye, et al., 2000). In respect of financial records, the respective percentages were 76 and 95. According to Tham-Agyekum et al. (2010), 100\% of all respondents kept production and financial records. Detailing the results, it was noted that $94 \%$ of the respondents kept records on the health of their animals, $62 \%$ kept labour records and $52 \%$ inventory records. Records on management practices were kept by $32 \%$ of respondents whiles $16 \%$ kept supplementary records. 
Alvarez \& Nuthall (2001) showed that all farmers kept both production and financial records on their operations. They noted that $54.48 \%$ of farmers used computer for financial record-keeping whilst $15.17 \%$ used manual financial record-keeping systems. It is instructive to note that, the manual system included cashbook recordings but excluded notes on calendars. Consequently, informal systems included the latter, as well as human memory. About $11 \%$ of respondents belonged to this category. To quote Doye et al. (2000), 'Managers interviewed valued the farm records highly in supporting achievement of goals. Producers expect the information system to result in better monitoring of financial performance and position, as well as production performance and processes. They also expect it to contribute to time saved, for instance, in processing transactions' $\mathrm{p}$. 582. These findings clearly suggest that production and financial records, however classified are the main concerns of farmers.

\subsection{Implications of Keeping Farm Records}

The ultimate purpose of record-keeping is to improve the level of herd performance by achieving better results, running the farm more competently or reducing the possibility of poor future performances (Jeyabalan, 2010). Chagunda et al, (2006) have established that, the efficiency of farm output can be increased through the practice of using a simple, precise, understandable and easy to maintain recording systems. In an earlier study, Mishra et $a l$, (1999) had observed that formal record-keeping systems were associated with higher farm profits. This was to be expected since computer adoption requires a relatively small fixed initial investment and the benefits of better record-keeping are likely to be significant (Grisham, 2007). Silver (2006) further added that, productivity of the small scale farmers can be enhanced by proper management practice emphasising that the most important management tool is proper record-keeping. Devonish et al., (2000), Chapman (2003) and Tham-Agyekum et al. (2010) have provided evidence that record-keeping enhanced opportunities of obtaining credit. Farmers are also able to provide needed information continuously for state and national farm policy decisions (Johl \& Kapur, 2001). This is vividly observed in Farm Management Associations (FMA) in the US where, according to Doye (2004) FMA have been in existence more than a century, and have provided substantial data for use of farmers and research as well as planning at the state and federal level. Indeed, FMAs are a means to promoting record-keeping among farmers (Gustafson, et al., 1990). A quote from Doye et al. (2000) is 'for decades, educators have encouraged record-keeping by developing .....as well as facilitating the formation of farm business management associations' p.1. Further, Gerloff \& Holland (1995) stated that government farm programmes require certain production and acreage records be reported and maintained by the farm owner.

\subsection{Factors Affecting Keeping of Farm Records}

Some factors are known to influence farm record-keeping. Batte, et al. (1995) in a study found that among farmers in Ohio State, age negatively impact adoption of formalised record-keeping. According to Mariene (1995) and Devonish et al., (2000), farm record-keeping is independent of age, gender, farm size, level of formal education and years of farming experience and confirmed by Zepeda (1994), and Holcomb et al., (2011). Alvarez \& Nuthall (2001) and Grisham \& Gillespie (2008) however reported a positive relationship between farm size and more record-keeping. Their results also indicated the contrary about age and record-keeping. They noted that younger farmers used more computerised record-keeping than older farmers. The research by Devonish et al., (2000) however, showed that there was a significant relationship between farm record-keeping and the following factors: farmer status, the receipt of credit and net income. Farmers who owned the larger farms tended to keep records than those with relatively smaller farms. Full-time farmers also tended to keep farm records than part-time farmers. Tham-Agyekum et al. (2010) did not find any difference in record-keeping behaviour between part-time and full-time farmers, indeed all kept production and financial records. Again, there was evidence that factors such as age, level of education, experience, status, size of farm and membership of association were independent of record-keeping. Hewlett (undated) noted that lenders used farm records as evidence to evaluate borrowers' repayment capacity and Devonish et al. (2000) further added that a higher proportion of farmers who kept records had obtained credit because their farm records were used to provide an indication of the viability of the farm business in order to receive credit from financial institutions. Farmers who keep farm records are likely to have higher incomes. Holcomb et al. (2011) however, did not find record-keeping distinguishing high-income farmers from low-income farmers. In respect of education, Zepada (1994), Batte et al. (1995a) and Batte et al. (1995b) noted that education increased use of formalised record-keeping. Tham-Agyekum et al. (2010) examined the association between some demographic characteristics using a chi-square test at 5\% level and concluded that age, educational level, experience in farming, farmer status, size of farm and respondents' membership of a farmer association was not associated with record-keeping. However, there was association between record-keeping and level of education. 
Farmers are unable to keep farm records owing to some constraints that militate against the good practice. These include, illiteracy (Minae et al., 2003); time required to keep records (Marcellino \& Wilson, 2006); size of farm operations and fear of paying taxes (Johl \& Kapur, 2001).

\section{Data and Methods}

Studies on farmers' adoption/use of information systems or record-keeping have predominantly employed primary data (Dernburg et al., 2007; Grisham \& Gillespie, 2007; Engler \& Roger, 2010, Tham-Ayekum et al., 2010). Hence, this study follows that path.

\subsection{Data Collection}

Grasscutter farmers association in Ga-South provided a list of 42 members. This number, according to Farmer Brown, the chairperson of the group, is the entire farmers of Grasscutter in Ga-South. Owing to the relatively small population, there was the need for an increase. A snowball procedure was employed. This led to substantial hike in number of the farmers. In the process, some of the farmers contacted were located in Awutu-Senya District of the Central Administrative Region of Ghana. In all 99 farmers were contacted. Questionnaires returned were 90 out of which 72 were usable. The data obtained was coded and entered into Statistical Package for Social Sciences (SPSS) version 18.

The instrument for data collection was a 20 -item questionnaire included in the appendix. The questions were made up of demographics, record-keeping and use of computers. The questionnaire was tested on a handful of farmers in the population. Upon corrections and amendments, the final questionnaire was administered to farmers in both and Ga-South Municipality and Awutu-Senya District.

\subsection{Data Analysis}

Technology adoption has been studied by use of some analytical tools. Descriptive statistics are simple and has often been used in conjunction with nonparametric tests and binary choice models. In order to study associations, Tham-Agyekum et al., (2010) used non-parametric tests such as chi-squares, whilst Dernburg et al., (2007) used odds ratio. Others have employed binary choice models for investigating factors that influence adoption (Just et al., 2003; Nuthall, 2004; Batte, 2005; Engler \& Toledo, 2010). The use of pairwise cross tabulations with chi-square tests is ineffective as the influence of other factors is not accounted for. Therefore in this study, a form of binary choice model; binary logit was employed. The virtue in this choice rested in the ability to incorporate all possible factors that may influence information system use. The binary logit model is specified as:

$$
L_{i}=\ln \left(P_{i} / 1-P_{i}\right)=\beta_{0}+\beta_{1} A_{i}+\beta_{2} E_{i}+\beta_{3} F S_{i}+\beta_{4} F S t_{i}+\beta_{5} \text { AsS }_{i}+\beta_{6} S_{i}+\beta_{7} \operatorname{Exp}_{i}+\beta_{8} \text { Income }_{i}+\mu_{i} \ldots
$$

Where $\mathrm{L}_{\mathrm{i}}$ is the $\log$ odds ratio, $\mathrm{P}_{\mathrm{i}}$ is the probability of using farm information system, $A$ is age, $E$. is highest level of education of farmer, $F S$ is whether the farmer is into Grasscutter rearing full time or part time and $F S t$ is farm size represented by the number of animals the farmer holds. Ass represents whether the farmer belongs to Grasscutter farmers' association or not, $S$ denotes the sex of the farmer, Exp denotes the experience of the farmer and Income represent farmer's income (Sales).

The use of farm information system is designated 1 whilst non-use is designated 0 . Age is measured in years, 1 is assigned to males and 0 if farmer is female with measurement of sex. Education is on a scale of 1 to $5 ; 1$ is for no formal education and 5 is for farmer with tertiary education. Membership of farmer association is given 1 and non-membership was assigned 0 . Size of farm is captured as the number of animals the farmer holds. Experience is how long farmer has been in Grasscutter production, measured in years. Income was captured as farmer's Grasscutter sales; below GHS500 denoted by 1, GHS500-1,000 designated as 2, GHS1, 001-5,000 captured as 3 and above GHS5000 represented by 4 . All other objectives outlined in section 1.3 will be attained using frequencies.

\section{Results and Discussions}

\subsection{Demographics}

A number of demographic dimensions of the respondents were investigated. The results show that most farmers constituting $44.4 \%$ of the sample aged between 41 and 50 years (Table 1). More than $80 \%$ of the farmers are aged 41 years and above. This high proportion points to ageing grasscutter farmers in the areas under study. The mean age of farmers is 48.7 years (Table 2), slightly higher than that for poultry farmers in Ga-East (Tham-Agyekum, 2010). The mean farm size, represented by number of grasscutter is 24 . The minimum of 2 
and maximum of 60 resulted in a range of 58 . The standard deviation of 16.6 (Table 2) is slightly lower than the mean. The longest time a farmer has been rearing grasscutter is 10 years with a mean of 4.3 years. This contrasts with 32 years for poultry farmers in Ga-East Municipality (Tham-Agyekum, 2010). The relatively short grasscutter rearing experience is suggestive of relatively recent effort on domestication of the rodent in the study area.

The sample comprised of $80.6 \%$ (58) males (Table 3). In terms of highest level of educational attainment, the mode of $36.1 \%$ relates to post-secondary certificate holders. With $0.0 \%$ not having any formal education, grasscutter farmers in the area under study are generally literate. This situation augers well for the industry in the study area as information and ability to be taught to and use farm information systems in English will be easier for agricultural extension staff. Those who engage in the rearing of the rodent full-time (46) exceed those who rear the rodent on part-time (26). With the majority in full time grasscutter rearing and the relatively low farm size, there may be challenges for profitability and sustainability of the enterprises. Those who belong to grasscutter farmers association (33) do not outnumber non association members (39). This suggests that leaders of the rodent association have some marketing to do in order to attract more members.

\subsection{Types of Farm Information Systems Used by the Grasscutter Farmers}

Farmers kept different kinds of records; breeding records, expenditure records, sales records, inventory and growers records (Table 4). Breeding records were mostly updated monthly whilst expenditure records were mostly updated weekly. Sales and inventory records were updated daily. This finding is similar to that of Ryde \& Nuthall (1984).

Following Omoruyi (1999) and Poggio (2006), the kinds of records kept were classified into four; financial records, production records, resources inventory and supplementary records. Table 5 shows that no farmer indicated keeping supplementary records. Most farmers (45, 62.5\%) kept production records. The relative popularity of production records is in line with the findings of Devonish et al., (2000), Doye, et al., (2000) and Okantah et al., (2003). This is so because production is the basic operations about a farm.

\subsection{Implications of Farm Information Systems}

From the literature review two implications were identified; record-keeping association with higher profits and higher credit access. The current study investigated the latter. Majority of the respondents $(46,63.9 \%)$ did not obtain credit (Table 6). Few (26) did obtain credit. Half of this number obtained credit from savings and loans companies, whilst the others obtained credit from either banks or credit unions (Table 7).

The size of the farms (mean of 23) suggests that the operators are largely very small scale. Hence, these institutions are the most appropriate for them. Deducing from few farmers obtaining credit and majority keeping records, positive association between record-keeping and credit access is unlikely. The results of an explicit test of this assertion are presented in Table 8 .

The test statistics show high levels of independence between the two constructs. Hence, the assertion of no statistically significant association between record-keeping and obtaining credit is confirmed among grasscutter farmers in Ga-South Municipality and Awutu-Senya District.

\subsection{Reasons for Non-use and Constraints of Grasscutter Farmers in Using Farm Information Systems}

Majority of grasscutter farmers $(55,76.4 \%)$ embraced the good practice of using farm information systems on their operations (Table 9).

This contrasts with the findings of Tham-Agyekum (2010) who noted all poultry farmers in Ga-East used some form of farm information system. Those who used farm information systems used books (47, 59.5\%), pieces of paper $(25,31.6 \%)$ and computer $(7,8.9 \%)$ as means of storing records (Table 10$)$ in line with the assertions of Hewlett (undated) and the findings of Ryde \& Nuthall (1984). The low level of computer use in farm information systems by grasscutter farmers in the study area contrasts with the findings of Ferrer et al, (2003) which noted $97 \%$ ownership and usage of computer in farm information management. The result however confirms the outcomes of Tham-Agyekum (2010) who noted about $2 \%$ of poultry framers in Ga-East Municipality owned and used computers in farm information system management. Those who used books and computers stored the materials in rooms whilst those who used pieces of paper hanged them in front or the side of grasscutter cages. Clearly, few respondents used computers. However, those who used farm information systems encountered some challenges. These include confusion with data, boring nature of activity, laziness towards the routine and inadequate data on newly purchased animals (Table 11). 
The reasons assigned by non-users of farm information system are too much work, no reason for non-use, inadequate time at their disposal to spare some for recording and no need to record since operations are not regular as in poultry rearing (Table 12). Jayabalan (2010) did acknowledge the time consuming nature of manual record-keeping.

\subsection{Factors Affecting Use of Farm Information Systems by Grasscutter Farmers}

Age, level of education, farm size, farmer status, membership of association, sex, experience and income were hypothesised to influence use of farm information systems (FIS). Equation 2 presents the empirical results. The signs of the coefficients for education, farm size and income are negative. The numbers in bracket are the Wald statistics. The results show that none of the estimated coefficients are significant at the $10 \%$ probability level.

$$
\begin{array}{rlrrr}
F I S= & -5.54+0.09 A_{i}-0.50 E_{i}-0.05 F S t_{i}+1.27 F S_{i}+20.93 \text { Ass }_{i}+3.16 S_{i}+0.16 \text { Exp }_{i}-0.63 \text { Income }_{i} \ldots \ldots \ldots \ldots \ldots . . . . .(2)
\end{array}
$$

This suggests that all the variables tested are independent of farm information systems use among grasscutter farmers in Ga-South and Awutu-Senya District. This result conforms to the findings of Zepada (1994), Mariene (1995), Devonish et al. (2001), Tham-Agyekum (2010) and Holcomb et al., (2011). The independence of age is contrary to the findings of Batte, et al. (1995) that age negatively impacts on record-keeping.

\section{Conclusion and Recommendations}

\subsection{Conclusions}

The study set out to investigate use of farm information systems among grasscutter farmers in Ga-South Municipality and Awutu-Senya District in Ghana. Specifically to accomplish the following: examine the demographic characteristics, identify the various types of farm information systems used, describe the implications of the use of farm information systems, identify the reasons for non-use and constraints in using farm information systems and determine the factors affecting use of farm information systems.

Majority of farmers were aged 41 years and above indicating an ageing situation among grasscutter farmers in the study area. The farmers operate on small scale with mean farm size of 24 grasscutters. Grasscutter rearing is male dominated and most of the respondents are literate as every respondent has at least basic school certificate. The farmers sampled used production records mostly. Other farm information systems used include financial and inventory records. None kept supplementary records. Contrary to popular believe, use of farm information systems did not show positive association with obtaining credit from formal credit institutions. The use of books and loose sheets to keep records of farm operations is most popular with the farmers. Use of computers is least popular. Those farmers who did not keep any form of farm record were in the minority. The reasons they adduced include too much work, no reason for non-use, inadequate time at their disposal to spare some for recording and no need for records since operations are not regular as in poultry rearing. Indeed the majority who kept records faced some challenges; confusion with data, boring nature of activity, laziness towards the routine and inadequate data on newly purchased animals. Age, level of education, farm size, farmer status, membership of association, sex, experience and income were found to be independent of farm information systems use.

\subsection{Recommendations}

With low female proportion and ageing sample, there is the need to encourage young people especially females to engage in the enterprise. The less than $100 \%$ adoption of use of farm information systems calls for effective promotion of use of farm information systems among grasscutter farmers. The benefit of accessing credit may not be an important benefit in the design of the training programmes on record-keeping. However, it must be stressed that with increased scale of operations, it will be necessary and will necessitate the need for credit hence use of farm information systems. An investigation into the causes of low farm size will unearth the causes and as such provide ways to increase farm size as most of the farmers are into full time grasscutter rearing. The low farm size, relatively old patrons of the farming enterprise raises questions about sustainability. This calls for vigorous promotion by government and non-governmental organisations. Since the majority of farmers do not belong to the grasscutter farmers association, the members need to step up their marketing promotion efforts to recruit more farmers into the association as associations are better to relate to and reach with extension effort.

\section{References}

Adams, J. S. (2009). Establishing a model to identify information systems in nontraditional organizations. Information Systems Education Journal, 7(88), 1-9. 
Ajayi, S. S., \& Tewe, O. O. (1980). Food preference and carcass composition of the grasscutter (Thryonomys swinderianus) in Captivity. African Journal of Ecology, 18, 133-140.

Akinbile, (2002). Grasscutter rearing as an urban agricultural practice in Ibadan Metropolis. African Journal of Livestock Extension, 1, 32-35.

Asibey, E. O. A. (1969). Wild animals and Ghana's economy (An Investigation into bush meat as a source of protein) Department of Game and Wildlife, Ministry of Lands and Forestry, Accra.

Asibey, E. O. A. (1974). Reproduction in grasscutter in Ghana. Symposium of Zoology Society London, 34, 161-170.

Batte, M. (2005). Changing computer use in agriculture: evidence of Ohio. Computer and Electronics in Agriculture, 47, 1-13. http://dx.doi.org/10.1016/j.compag.2004.08.002

Batte, M. T., Jones, E. \& Schnitkey. G. D. (1990). Computer use by Ohio commercial farmers. American Journal of Agricultural Economics, 4, 935-945. http://dx.org/10.2307/1242625

Batte, M. T., Rister, M. E. Frank, G. \& Schnitkey. G. D. (1995). Farm information systems design and use by selected demographic and business characteristics. In M.T. Batte, (ed.) Adoption and Use of Farm Information Systems. Wooster, OH: Ohio Agricultural Research and Development Center Special Circular 149; North Central Regional Research Publication, 339, 11-35.

Byanet, O., Onyeanusi, B. I. \& Ibrahim, N. D. G. (2009). Sexual dimorphism with respect to the macro-morphometric investigations of the forebrain and cerebellum of the grasscutter (Thryonomys swinderianus). International Journal of Morphology, 27(2), 361-365. http://dx.doi.org/10.4067/S0717-95022009000200010

Carkner, R. W. (2000). Farm business records: An introduction, Farming West of the Cascades Series of Washington State University No. EB1904.

Chagunda, M. G. G., Msiska, A. C. M., Wollny, C. B. Tchale. A. H., \& Banda, J. W. (2006). An analysis of smallholder farmers' willingness to adopt dairy performance recording in Malawi. Livestock Research for Rural Development, 18(5). Retrieved from http://www.lrrd.org/lrrd18/5/chag18066.htm

Chapman, M. E. N. (2003). Keeping farm records in Sudan. Historical Document, Kansas Agricultural Experiment Station. http://dx.doi.org/10.1177/095207670301800305

Clotey, A. (1981). Relation of physical body composition to meat yield in the grasscutter (Thryonomys swinderianus Temminx). Ghana Journal of Science, 21, 1-7.

Dernburg, A. R., Fabre, J., Philippe, S., Sulpice, P., \& Calavas, D. (2007). A study of the knowledge, attitudes and behaviours of French dairy farmers toward the farm register. Journal of Dairy Science, 90 (4). http://dx.doi.org/10.3168/jds.2005-223

Doye, D. (2004). The use of electronic technology in teaching farm record keeping. American Journal of Agricultural Economics, 86(3), 762-766. http://dx.doi.org/10.1111/j.0002-9092.2004.00621.x

Engler, A., \& Toledo, R. (2010). An Analysis of factors affecting the adoption of economic and productive data recording methods of Chilean farmers Ciencia $e$ investigation agrarian, 37(2), 101-109. http://dx.doi.org/10.4067/S0718-16202010000200010

Ferrer, S. R. D. Schroder, D. H. \& Ortmann, G. F. (2003). Internet use and factors affecting adoption of internet applications by sugarcane farm businesses in the Kwazulunatal Midlands. Contributed paper presented at the 41st Annual Conference of the Agricultural Economic Association of South Africa (AEASA), October 2-3, 2003, Pretoria, South Africa

Feyenuwo, J. O., Modupe, A., Oluokun, J. A., \& Ogundola, F. I. (1998). Grasscutter domestication and multiplication. Farmers Guide. IAR\&T. Ibadan Nigeria. Pp.10.

Grisham, E. (2007). Record-keeping systems adoption by Louisiana dairy farmers. Unpublished M.S. Thesis, Louisiana State University, Baton Rouge, LA. http://dx.doi.org/10.1094/PDIS-91-4-0453

Grisham, E. \& Gillespie, J. (2007). Record-keeping technology adoption in the Louisiana dairy industry Selected Paper prepared for presentation at the Southern Agricultural Economics Association Annual Meetings, Mobile, Alabama, February 3-7, 2007. 
Gustafson, C. R., Neilson. E. \& Morhart, M. J. (1990). Comparison of the financial results of record-keeping and average farms' in North Dakota. North Central Journal of Agricultural Economics, 12 (2). http://dx.doi.org/10.2307/1349369

Hadawy, S. A., Poursadegh, N, Zeinab, N. B. \& Khavandi, R. (2011). Developing an strategy for Mobin Petrochemical Company by using balanced scorecard attitude. Business Intelligence Journal, 4(1), 129-141.

Happloid, D. C. D. (1987). A population study on small rodents in the tropical rainforest of Nigeria. Terre, vie 31, pp.385-458.

Heul-Rolf B. (2002). Grasscutter promotion in Ghana-GTZ support. Proceedings of workshop on promoting grasscutter production for poverty reduction in Ghana, (eds.) Atta-Agyapong, K \& Weidinger, R. October 16-18, 2002, Sunyani, Ghana. Qualitype Printing and Graphics, Accra, Ghana, pp. 5-7.

Hewlett, J. P. (undated). Farm/Ranch information systems managing for today's cattle market and beyond Retrieved from: http://www.uwagec.org/marketing/MngTCMkt/FrmRnchIn.pdf

Holcomb, R., Olson, K., Hachfeld, G., Bau, D., \& Kurtz J. (2011). Producer attitudes, assistance, and time allocation affecting farm income. Ag. Business Management, University of Minnesota Extension.

Jeyabalan, V. (2010). Individual cow recording and analysis system for small scale dairy farmers in Malaysia. International Journal of Computer Applications, 8(11). http://dx.doi.org/10.5120/1247-1621

Jofre-Giraudo, E., Streeter, D. H., \& Lazarus, W. (1990). The impact of computer information systems on dairy farm management decisions. Agribusiness, $463-474$. http://dx.doi.org/10.1002/1520-6297(199009)6:5<463::AID-AGR2720060505>3.0.CO;2-A

Johl, S. S., \& Kapur, T. R. (2001). Fundamentals of Farm Business Management. Kalyani Publishers, pp. 253-259.

Just, R., Wolf, S., \& Zilberman, D. (2003). Principles of risk management services relations in agriculture. Agricultural Systems, 75, 199-213.

Kyle, R. (1987). Feasi in the Wild. Oxford: Kudu Publishing

Lasley, P. \& K. Agnitsch. (2002). Iowa farm and rural life poll: 2002 Summary Report. PM 1915. Iowa State University Extension.

Laudon, J. C. \& Laudon, J. P. (2002). Management information systems: Managing the digital firm, 7th ed. Prentice-Hall, Englewood Cliffs, NJ.

Marcelino. D. M., \& Wilson. C. A. (2006). The current state and value of farm record keeping. Proceedings of Regional Research committee NC-1014 Washington, DC, October 2-3, 2006.

Martin, G. H. G. (1985). Carcass composition and palatability of some wild animals commonly used as food. World Animal Review, 53, 40-44.

Minae, S., Baker, D., \& Dixon, J. (2003). Status of farm data systems and farmer decision support in Sub-Saharan Africa, FAO Rome, 2008.

NRC. (1991). Quality-Microlivestock-Little known small animals with a promising economic future. Washington, DC: National Academy Press. 147-155.

Nuthall, P. (2004). Case Studies of interactions of farm profitability and the use of a farm computer. Computer and Electronics in Agriculture, 42, 19-30. http://dx.doi.org/10.1016/S0168-1699(03)00084-X

Onadeko, S. A. (1996). The reproductive ecology of the grasscutter (Thryonomys swinderianus) in captivity Unpublished Ph.D. Thesis, Department of Wildlife and Fisheries Management, University of Ibadan, 190pp.

Poggio, M. (2006). Farm Management Records. Retrieved from: www.srdc.gov.au

Ryde, J \& Nuthall, P. L. (1984). farmers record keeping and planning practices: A postal survey, Research Report, Agricultural Economics Research nit, Lincoln College, Canterbury, New Zealand

Silver, K. (2006). Dairy records management. Kosovo Cluster and Business Support Project report, 1-18.

Taiwo, O. W. (2006). Grasscutter farming is lucrative. Tribune, Tuesday, 20 June, p 8.

Tham-Agyekum, E. K., Appiah, P. \& Nimoh, F. (2010). Assessing farm record keeping behaviour among small-scale poultry farmers in the Ga East Municipality. Journal of Agricultural Science, 2(4), 52-62. 
Van de Velde, M. (1991). L'elevage d'aulacodes au Zaire. Puli. Service Agric. no. 27. Administration Generale de la Cooperation Belge. (English version of abstract was used.)

Vos, A. D. (1978). Game as food: A report on its significance in Africa and Latin America. Unasylver, 4, 2-12.

Wontewe C. (2002). Action Aid Ghana contribution to grasscutter promotion in Ghana. Proceedings of workshop on promoting grasscutter production for poverty reduction in Ghana, Eds.) Atta-Agyapong, K and Weidinge, R. October 16-18, 2002, Sunyani, Ghana. Qualitype Printing and Graphics, Accra, Ghana, pp. 7-9

Zepeda, L. (1994). Simultaneity of technology adoption and productivity. Journal of Agriculture and Resource Economics, 19(1), 46-57.

Table 1. Demographic Characteristics 1

\begin{tabular}{|l|c|c|c|}
\hline Age Range & Frequency Count & Percentage Frequency & Cumulative Frequency \\
\hline 20 and below & 0 & 0 & 0 \\
\hline $21-30$ & 0 & 0 & 0 \\
\hline $31-40$ & 13 & 18.1 & 18.1 \\
\hline $41-50$ & 32 & 44.4 & 62.5 \\
\hline $51-60$ & 20 & 27.8 & 90.3 \\
\hline 61 and above & 7 & 9.7 & 100.0 \\
\hline
\end{tabular}

Source: Field data, 2011.

Table 2. Demographic Characteristics 2

\begin{tabular}{|l|c|c|c|c|}
\hline \multicolumn{1}{|c|}{ Demographic } & Minimum & Maximum & Mean & Std. Deviation \\
\hline Age & 40 & 68 & 48.74 & 8.635 \\
\hline Number of Grasscutter & 2 & 60 & 23.72 & 16.645 \\
\hline Length of experience in Grasscutter & 2 & 10 & 4.33 & 3.045 \\
\hline
\end{tabular}

Source: Field data, 2011.

Table 3. Demographic Characteristics 3

\begin{tabular}{|l|c|c|c|}
\hline Demographic & Representation & Count Frequency & Percentage Frequency \\
\hline Sex & Male & 58 & 80.6 \\
\cline { 2 - 4 } & Female & 14 & 19.4 \\
\hline \multirow{5}{*}{ Education } & No formal education & 0 & 0 \\
\cline { 2 - 4 } & Basic (Primary/JHS) & 20 & 27.8 \\
\cline { 2 - 4 } & SHS/Technical/Vocational & 12 & 16.7 \\
\cline { 2 - 4 } & Post Secondary & 26 & 36.1 \\
\cline { 2 - 4 } & Tertiary & 14 & 19.4 \\
\hline \multirow{4}{*}{ Farmer Status } & Full time & 46 & 63.9 \\
\hline Membership of & Part Time & 26 & 36.1 \\
\cline { 2 - 4 } Association & Yes & 33 & 45.8 \\
\cline { 2 - 4 } & No & 39 & 54.2 \\
\hline
\end{tabular}

Source: Field data, 2011. 
Table 4. Frequency of Keeping Records

\begin{tabular}{|l|c|c|c|c|}
\hline Kinds of Records & Daily & Weekly & Monthly & Yearly \\
\hline Breeding & $0(0 \%)$ & $6(45 \%)$ & $45(62.5 \%)$ & $0(0 \%)$ \\
\hline Expenditure & $0(0 \%)$ & $19(26.4 \%)$ & $0(0 \%)$ & $0(0 \%)$ \\
\hline Sales & $19(26.4 \%)$ & $7(9.7 \%)$ & $0(0 \%)$ & $0(0 \%)$ \\
\hline Inventory & $7(9.7 \%)$ & $6(8.3)$ & $0(0 \%)$ & $0(0 \%)$ \\
\hline Growers & $0(0 \%)$ & $6(8.3)$ & $0(0 \%)$ & $0(0 \%)$ \\
\hline
\end{tabular}

Source: Field data, 2011.

Table 5. Types of Records

\begin{tabular}{|l|c|c|}
\hline Records & Count Frequency & Percentage Frequency \\
\hline Financial & 19 & 26.4 \\
\hline Production & 45 & 62.5 \\
\hline Resource Inventory & 7 & 9.7 \\
\hline Supplementary & 0 & 0.0 \\
\hline
\end{tabular}

Source: Field data, 2011.

Table 6. Credit Access

\begin{tabular}{|l|c|c|}
\hline Farm Credit & Frequency count & Percentage Frequency \\
\hline Yes & 26 & 36.1 \\
\hline No & 46 & 63.9 \\
\hline Total & 72 & 100.0 \\
\hline
\end{tabular}

Source: Field data, 2011.

Table 7. Sources of Credit

\begin{tabular}{|l|c|c|}
\hline & Frequency Count & Percentage Frequency \\
\hline Banks & 7 & 26.9 \\
\hline Savings \& Loans & 13 & 50.0 \\
\hline Credit Union & 6 & 23.1 \\
\hline Total & 26 & 100.0 \\
\hline
\end{tabular}

Source: Field data, 2011.

Table 8. Chi-Square Tests of cross tabulation of obtaining credit and record-keeping

\begin{tabular}{|l|c|c|c|c|c|}
\hline & Value & df & Asymp. Sig. (2-sided) & Exact Sig. (2-sided) & Exact Sig. (1-sided) \\
\hline Pearson Chi-Square & $0.006^{\mathrm{a}}$ & 1 & 0.936 & & \\
\hline Continuity Correction $^{\mathrm{b}}$ & 0.000 & 1 & 1.000 & & \\
\hline Likelihood Ratio & 0.006 & 1 & 0.936 & & 0.588 \\
\hline Fisher's Exact Test & & & & 1.000 & \\
\hline Linear-by-Linear Association & 0.006 & 1 & 0.936 & & \\
\hline N of Valid Cases & 72 & & & & \\
\hline
\end{tabular}

a. 0 cells $(.0 \%)$ have expected count less than 5 . The minimum expected count is 6.14 .

b. Computed only for a $2 \times 2$ table. 
Table 9. Keep records on farm Operations

\begin{tabular}{|l|c|c|}
\hline & Frequency Count & Percentage Frequency \\
\hline Yes & 55 & 76.4 \\
\hline No & 17 & 23.6 \\
\hline Total & 72 & 100.0 \\
\hline
\end{tabular}

Source: Field data, 2011.

Table 10. Mode of Keeping Farm Records

\begin{tabular}{|l|c|c|c|}
\hline & Count & Percentage & Percentage of Cases \\
\hline Storage of record (on Book) & 47 & $59.5 \%$ & $65.3 \%$ \\
\hline Storage of record (in front or side of cage) & 25 & $31.6 \%$ & $34.7 \%$ \\
\hline Computer & 7 & $8.9 \%$ & $9.7 \%$ \\
\hline Total & 79 & $100.0 \%$ & $109.7 \%$ \\
\hline
\end{tabular}

Source: Field data, 2011.

Table 11. Difficulties with Keeping Farm Records

\begin{tabular}{|l|c|c|c|}
\hline Reasons & Frequency count & $\begin{array}{c}\text { Percentage } \\
\text { Frequency }\end{array}$ & $\begin{array}{c}\text { Percentage of } \\
\text { Cases }\end{array}$ \\
\hline Confusion of data sometimes & 49 & $24.40 \%$ & $80.30 \%$ \\
\hline Can be boring sometimes & 49 & $24.40 \%$ & $80.30 \%$ \\
\hline Forgetfulness & 42 & $20.90 \%$ & $68.90 \%$ \\
\hline Feel lazy & 40 & $19.90 \%$ & $65.60 \%$ \\
\hline Keep but not keen about it & 15 & $7.50 \%$ & $24.60 \%$ \\
\hline Inadequate data on newly purchased animals & 6 & $3.00 \%$ & $9.80 \%$ \\
\hline Total & 201 & $100.00 \%$ & $329.50 \%$ \\
\hline
\end{tabular}

Source: Field data, 2011.

Table 12. Reasons for not keeping Farm Records

\begin{tabular}{|l|c|c|c|}
\hline & Frequency count & Percentage Frequency & Percentage of Cases \\
\hline Too much work for me & 16 & $32.7 \%$ & $94.1 \%$ \\
\hline No reason & 16 & $32.7 \%$ & $94.1 \%$ \\
\hline No time & 12 & $24.5 \%$ & $70.6 \%$ \\
\hline Do not give drugs like poultry & 5 & $10.2 \%$ & $29.4 \%$ \\
\hline Total & 49 & $100.0 \%$ & $288.2 \%$ \\
\hline
\end{tabular}

Source: Field data, 2011. 


\section{Questionnaire}

The Use of Farm Information Systems among Rodent Farmers in Ga South Municipality and Awutu-Senya District

\section{Introduction}

A researcher/Lecturer from the Department of Agribusiness of the Central University College is undertaking a study with the objective of assessing the use of farm information Systems among grasscutter farmers. This is purely an academic exercise, therefore an accurate and truthful response is required, and your responses will be kept with the strictest confidentiality.

\section{Personal Data}

1. Age:

2. Sex: Male. Female.

3. Highest Education Educational Level
a. No Formal Education
b. Basic (Primary/JHS)
c. SHS/Tech/Voc.
d. Post Secondary
e. Tertiary.....

4. Farmer Status: Full time: ..Part Time

5. Do you belong to any farmer Association? Yes. No.

6. How many animals do you have now?

7. How long have you been farming

8. Do you keep records on your farm operations? Yes. No.

9. If no, what are your reasons?

10. If yes, to question 8 , what are your reasons for keeping farm records?

11. What types of farm records do you keep? (Please mention all and/explain) 
12. How often do you put down records?

a. Daily.....

b. Weekly

c. Monthly

d. Yearly

13. How do you keep/store your records?

a. In my head (memory).

b. Manually

i. On wall.......Calendar.......Loose paper.......Book.

Others (specify).....

c. Computerised

i. Software used: Word.........Excel........Access.........PowerPoint...

ii. Specialised software? Specify

14. If you indicated a. in 8 , what difficulties do you have with it?

15. Do you obtain loan/credit? Yes

No.

16. From which institutions? Formal.

Informal.

17. Have ever received Farmers' Day Awards? Yes

No.

18. Estimate your sales per year.

\begin{tabular}{|l|l|}
\hline Sales Band & \\
\hline Below 500 & \\
\hline $500-1,000$ & \\
\hline $1001-5,000$ & \\
\hline Above 5,000 & \\
\hline
\end{tabular}

19. Problems encountered with Farm Record-keeping

20. Do you use a computer on your/for your farm business? Yes

Thanks so much for your attention and responses. 